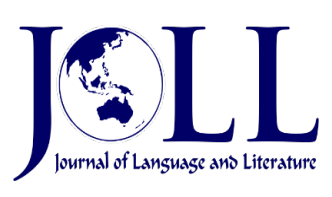

Vol. 21 No. 1, April 2021, pp. 137 - 147

DOI: 10.24071/joll.v21i1.2911

Available at https://e-journal.usd.ac.id/index.php/JOLL/index

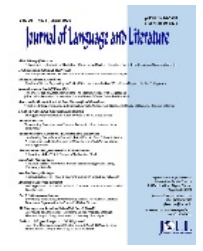

This work is licensed under a Creative Commons Attribution-ShareAlike 4.0 International License.

\title{
Realism and Naturalism in Samrat Upadhyay's The Guru of Love
}

\author{
Bimal Kishore Shrivastwa \\ bimalksrivastav@gmail.com \\ Department of English, Tribhuwan University, NEPAL
}

\begin{abstract}
This research project seeks to explore realism and naturalism in Samrat Upadhyay's novel, The Guru of Love, in the context of Nepalese society. It analyses how the novel delineates a realistic account of Nepalese middle-class people's hardships, struggles, and problems they face internally and externally through the character of Ramchandra, the protagonist of the fiction, an ordinary mathematics teacher who faces some hindrances in search of a better life and developing a career in the capital city. The principal objective of the study is to find the realistic, naturalistic, and materialistic elements in the novel, to examine the psychic predispositions that characters come through realistically, and to analyze the role of love and sex in terms of spirituality and emancipation as they all fall into the parameters of naturalism and realism. This study is developed through a theoretical framework based on realism and naturalism for the close textual analysis of the novel. The principal finding of the research paper is that the major characters of the novel, The Guru of Love, suffer from the conflict between their desires and their socio-economic realities. The article also surveys how material prosperity fails to resolve all the problems that human being goes through. It is expected that the paper stands as a reference for the research scholars interested to explore in the area.
\end{abstract}

Article

information

Received:

19 October

2020

Revised:

26 December

2020

Accepted:

29 December

2020

Keywords: hardships; substantiality; verisimilitude; worldliness.

\section{Introduction}

A literary realist claims to mirror or represent the world as it objectively appears while a naturalist links realism to determinism (Gary Scharnhorst, 2017). Samrat Upadhyay, the first Nepali-born fiction writer writing in English to be published in the West (Walsh, 2003), is an emerging writer of Nepali Diaspora, and a master of illuminating the characters' complex psyche in actual shape in his novels. Min Pun (2017) observes that Nepali writing in English, initiated by Laxmi Prasad Devkota, gained its momentum with the publication of Samrat Upadhyay's Arresting God in Kathmandu (2000), his first book which earned him a Whiting Award. His novel, The Guru of Love (2003) became a New York Times Notable Book, a San Francisco Chronicle Best Book of the Year, and a Book Sense 76 pick ("Samrat Upadhyay", n. d.). His novel, The City Son, 
published by Soho Press in 2014 was shortlisted for the PEN Open Book Award in the very year of its publication. Like Chekhov, Samrat Upadhyay speaks to common truths startlingly good (Tamara Straus, 2001).

Born in 1963 in Kathmandu, Nepal, Upadhyay moved to the United States at the age of twenty-one to attend the undergraduate degree from the College of Wooster in Ohio and achieved Ph.D. from the University of Hawaii in 1999. Currently, he is the Martha C. Kraft Professor of Humanities at Indiana University in the US, where he teaches creative writing. Oindrila Mukharjee (2014) deems that Upadhyay deconstructs the myth that surrounds the people of Kathmandu. Upadhyay demonstrated skills for depicting the dynamics of people and the complexities of relationships in his novels (Min Pun, 2017).

The Guru of Love is a moving and important story; important for what it illuminates about the human need to love as well as lust, and for the light, it shines on the political situation in Nepal and elsewhere (F. Leebron, 2003). The Guru of Love tells the story of a lowly tutor who ends up in a most irregular domestic ménage. This book has plenty of realistic and naturalistic impulses. "The Guru of Love examines a web of dependencies, not unexpected in a traditional, but changing society" (Dickinson, 2003). Ramchandra, a quiet math teacher, reluctantly enters into an adulterous relationship, and soon his double lives disastrously converge. When Goma, his wife by arranged marriage, learns of his affair, she demands that his mistress moves into their small quarters.

Unable to dissuade her, Ramchandra finds his desires and fears living side by side. Goma proves to befar shrewder than she seems, entering into a surprising alliance with his mistress. And Ramchandra finds himself trapped- both in his house and in his city, Kathmandu, a crowded place where secrets are impossible to keep and family matters dictate. Ultimately, his only escape is to let go of someone he loves. Seeman (2002) advocates, "Absorbing, sexy and psychologically acute, The Guru of Love radiates compassion and rare insight" (para. 2). All the truthful representations of personal, political events that occur in the novel provoke a researcher to analyze the text from different layers of realism and naturalism.

All of Samrat Upadhyay's novels, including The Guru of Love, have received critical appraisal from all over the world. Critics have proffered striking and valuable judgments on the theme, characterization, narrative technique of The Guru of love after its publication in 2003. The Guru of Love, set against a backdrop of unrest in contemporary Kathmandu, tells the story of a lowly tutor who ends up in a most irregular domestic ménage ("The Guru of Love", n. d.). "Guru of Love is moving and important story, important for what it illuminates about the human need to love as well as lust, and for the light it shines on the political situation in Nepal and elsewhere" ("The Guru of Love by Samrat Upadhyay", n. d., para.1).

Judging on the theme of the novel, in the view of Mehta (2003), "This book brings us back down into thick air, to the congested, smoggy valley of Kathmandu, not the Kathmandu of Western seekers of salvation or hashish" (p. 12). Kalita (2003) remarks that despite the brevity and conciseness rare in the literature about South Asia, The Guru of Love effectively weaves together the complicated dichotomies of man and mistress, love and lust, tradition and modernity". Frederic and Mary Ann Brussat (2003) survey that the interplay between the outer and the inner tensions in Kathmandu and Ramchandra's soul is represented well. They further opine that the most impressive thing about this engaging novel is Upadhyay's compassion for all the characters, especially the unusual ways they respond to the jolts of adultery and familial upset.

Ramchandra's long-suffering wife comes up with a unique and, in the long run, healing and helpful solution to the affair. Descriptions of local religious customs, arranged marriages, matching between the castes, and consequences if the match fails, were very interesting (Milan/zzz, 2008). Nair (2003) opines that the great merit of Upadhyay's 
unpretentious book, The Guru of Love, is that it recounts the story of this other Nepal:

On the one hand, we see the country projected in bromide tourist bytes as a superbly antique Hindu kingdom, the land of the Buddha's birth and so forth; and on the other, Nepal's modern avatar in Indian newspapers is of a land fraught with the deadliest insurrections. (pp. 7-8)

Kate Wheeler (2008) observes that unsentimental detail, delicate realism assists us to recognize, with compassion and awareness, the stories and feelings of which our lives are composed. Samrat Upadhyay has explored love, lust, and marital relation only at a surface level. Although "The Guru of Love is a story of contemporary Kathmandu, the Nepali readers may find the book quite unnatural and unsatisfactory" ("Upadhyay's novel The Guru of Love", n. d., para.1). Kenzom La (2015) surmises that the way the characters are drawn together by Upadhyay and the timeliness of strings of events that occur is laudable. Samrat Upadhyay has mastered over realism. He portrays Kathmandu and the livelihood of people in a very beautiful way (Anup Joshi, 2016).

Although a wide variety of criticisms is made about The Guru of Love, there are many fields about this text which remain unexplored. The realistic and naturalistic study is one of them. Therefore, this research explores Samrat Upadhyay's The Guru of Love from the theoretical modality of realism and naturalism.

\section{Methodology}

The study develops a theoretical modality based on the principals of realism and naturalism. The primary data of this research is the novel, The Guru of Love by Samrat Upadhyay. The systematic sampling method is used to justify the working hypothesis. This paper applies a qualitative approach to research by using the primary resource, that is, the text itself, and secondary resources such as literature from journals, websites commentaries. Its delimitation primarily lies in studying the text from the realistic and naturalistic perspectives while assessing the novel, The Guru of Love.

The major characters of the novel suffer from the conflict between their desires and their socio-economic realities. The main character, Ramchandra, goes through a tripolar conflict: his economic condition, professional morality, and sexual desire, internally and externally. The problems that this study states are: What hardships, struggles, and problems have the characters faced? How are they resolved or not? To analyze these problems, intensive analysis of the text is done from a realistic and naturalistic perspective. Furthermore, materialism is the supporting theoretical framework for the study. The naturalistic and realistic discourse has provided the researcher chances to understand the text better.

John Dudley (2012) views realism as a mode of writing that gives the impression of recording or reflecting faithfully an actual way of life. Modern criticism frequently proposes that realism is not a direct or simple reproduction of reality or a slice of life, but a system of convention producing a lifelike illusion of the real world outside the text, by process of selection, exclusion, description, and manners of addressing the reader. A reaction against romanticism and an interest in the scientific method of the systematizing of the study of documentary history and the influence of rational philosophy affected the rise of realism (Micheal Dummett, 1982). Realistic novels avoid the sensational, dramatic elements of naturalistic novels and romances.

Monika Bhagat-Kennedy (2014) argues about realism as one of the oldest progressive theories of criticism which had a significant role to develop Marxism. Realism came to fruition as a helix of empiricist philosophical development that of English Francis Bacon and John Locke, and Rene Descartes, and so on. Putnam Hilary (2015) thinks naturalism is a more deliberate kind of realism in novels, stories, and plays usually involving a view of human beings as passive victims of natural forces and social environment. Naturalists believe that every human being was determined by the forces of heredity and environment. Donna M. Campbell 
(2017) opines that 'Naturalism' is sometimes claimed to give an even more accurate depiction of life than in realism. Naturalism was distinctively a mode of fiction that was developed by a school of writers following a particular philosophical thesis. This thesis, a product of post-Darwinian biology in the 19th century, holds that a human being exists entirely in the order of nature and does not have a soul beyond nature, and therefore, that such a being is merely a higher-order animal whose character and behavior are entirely determined by two kinds of forces: genetic and society.

\section{Results and Discussion}

From the very initial stage, Samrat Upadhyay draws the unique characterization and incidents with noticeable emergence in The Guru of Love. And after introducing the character, the writer often talks about his behavior, the thought-processes to highlight how the family, social conditions, and the environment of the character are important in shaping human character. In realism, the character is more important than action and plot, and in naturalism, complex ethical choices of the character signify how his environment determines human behavior (Phillip Barrish, 2011). Characters appear in their real complexity of temperament and motive in the novel, The Guru of Love.

Ramchandra, the protagonist, and his family are unhappy because of economic deprivation that he fails to fulfill his family requirements due to his limited earning. Very specifically, he is unhappy because his struggle to build a house goes in vain. Goma, his wife, is unhappy because of Ramchandra's illicit relationship with Malati. Pandey's, Goma's parents, are unhappy as they can't bear a son to claim their property. Malati is unhappy as she is betrayed by her lover leaving her pregnant. However, struggles, hardships, and problems are common to all. The novel records Ramchandra's physical and psychological hardships and his efforts to fight against them. He spends his entire physical and mental power to improve his monetary status. Psychologically, he is always hit by insult and criticism either at home or at work. As Ali Taghizaden (2014) regards, "objectivity of the presentation becomes increasingly important in realism" (p. 1628), the novelist, Upadhyay has endeavored to present plot and actions objectively.

Ramchandra, a government school Mathematics teacher fights his whole life against his economic restrictions. After his father's untimely demise, ill-fortune began to chase him. He struggles to build a career in the city. The days when he was in his original place at Lamjung, the eastern part of the country, were comparatively easy. They had got a small house of their land. People around them were more cooperative and warm-hearted than in Kathmandu. His childhood days make him nostalgic: "Ramchandra's own memories of Lamjung remained clear. The general store in a mud house perched dangerously on top of a hill" (p. 5).

The setting of Samrat Upadhyay's novel The Guru of Love is Kathmandu, the capital city of Nepal. The novelist has mentioned some of the oldest parts of the city and some modern. During the Panchayat (One-party) autocratic system in Nepal, the Royal Palace was the pillar of political power, and Tri-Chandra College, Padmakanya College, and other major colleges in the city were the center of antiautocratic movements. In Kathmandu, expanding and increasing malpractices such as corruption, nepotism, tough and unfair competition, and losing humanity under the shadow of development, modernization and civilization lead life towards negative virtues that affect every aspect of life.

Irregularities and malpractices created by the wrong political system and corrupt bureaucrats directly affect common people. Apart from personal obligations, society and the system are the cause of the hardships that Ramchandra and other characters have to face. Ramchandra's financial struggle begins when he enters the city with hope and expectations that he never achieves. Tension and melancholy follow him until he can own a house of his own. Until he graduated, his widowed mother bore all sorts of hardships, struggles, and problems. But as he grew up and educated, all responsibilities came to him. At the beginning of his days in Kathmandu, he 
lived in a narrow room no larger than a bathroom.

There were not sufficient toilets and bathrooms, not sufficient water supply for drinking and sanitation. His mother used to serve rich people from hand to mouth. He took tuition classes and earned a little money. After completing his post-graduate in mathematics, Ramchandra wandered here and there to find a good job. He was not an origin of Kathmandu and none of his relatives were in powerful positions. Corruption and nepotism are common in the city for some to shape their career. When his mother became older and unhealthy, his responsibility to feed her intensified his financial struggle. As it happens in the case of realist people, he is impelled to chase materialism. Materialism holds that mind and consciousness are the by-products of the material process (M. Nilgel \& E. Sauri, 2013). Unwillingly, he joins as a part-time teacher in a ruined private school where he is treated like an animal by the owner of the school who made his work hard and paid him little.

Every winter chilled him cruelly. His limited earning is not sufficient to afford the necessary clothing and modern types of equipment to get rid of cold weather. The ceiling and walls of the rented house have been cracked; his electric heater does not produce proper heat. For travel, he does not have any vehicles, even a bicycle. Likewise, he is obliged to live without a television for information and entertainment, and telephone for communication:

One of the coils of the heater had come loose, and it protruded dangerously; still glowing red. He'd have to fix it soon, before the children burned themselves on it, before the coming months of winter, when even the fish feel cool, as Ramchandra's mother used today. (p. 2)

His regular salary is not enough for his family's expense so he has to do more than that. He earns some amount from seasonal tuition classes. Mario De Caro (2011) believes that naturalism is a metaphilosophy of our time. A person inherits compulsive instincts, especially hunger, the accumulative drive, and is then subject to the social and economic forces in the family, the class, and the milieu into which that person is born (Audi Robert, p. 372). Ramchandra faces the same. Ramchandra couldn't afford to celebrate festivals. When festivals approached, his children seemed excited expecting beautiful new clothes, toys, and delicious foods. Children wish whatever their friends and neighbors wear and play. Every festival tortured Ramchandra because, for him, they meant more expense. He talked to his wife about how to manage for coming to Dashain and Tihar, the greatest festivals:

Dashain was only a week away, with Tihar chasing at its heel. It meant that Ramchandra had to dip into his savings to get new clothes for the family, plus at least a hen, if not a goat, for sacrifice to the goddess. (p. 10)

Fortune drives him to marry a daughter of a well-to-do family. His marriage changes into misfortune after all because the status between them do not match. Goma, his wife, does not feel comfortable living in such a congested old flat. Her younger sister, Nalini, gets married to Harish, a successful businessman. His inlaws always appreciate Harish, but they neglect him either directly or indirectly. In past, Harish was educated in a reputed English school in Darjeeling and Delhi, but Ramchandra had taken a rural government Nepali school. They wished Ramchandra to be rich enough to make a house in the city. They seem to be regretful for accepting him as their son-in-law. When he was offered Goma's hand to him, they had thought that he would achieve a higher post, be able to earn a lot of money, and be rich. But now his motherin-law is more critical to him. The environment had governed the behavior of the entire family, as found in the extreme type of realism and naturalism.

Ramchandra has learned the importance of materialism. Materialism denies the existence of both deities and souls. In most of Hinduism and transcendentalism, all matter is believed to be an illusion called Maya, blinding us from knowing the truth. Ramchandra thinks that if he had at least a house, he could live more freely and happily. He would not be criticized and insulted by his in-laws. Similarly, 
he would not be worried about the increment of house rent, and he would not have any arguments with the house lords. He has tried to save as much as he can for a house of his own. His wife, Goma, prays the Hindu Goddess Laxmi, the goddess of wealth, to bless them with wealth. Goma imagines a house of her own. She dreams to possess just a beautiful small house. To resolve from her repressed mind, she enjoys drawing. Once she draws two houses; one represents her maternal grandparents', the Pandey Palace, and another her dream house, 'Acharya Hut'. The drawing better exposes her unconscious mind, the result of feeling inferior:

The drawing was of a large mansion, and the caption at the bottom, read PANDEY PALACE. The two people standing above the house were labeled Grandfather and Grandmother. Their faces were clearly unhappy; drooping curves were drawn as their lips. Above the Grandfather's head she'd written "The Guru of Money". Alongside the mansion was a small house with broken windows (Sanu had neatly cut the windows in half, with jagged lines showing their panes), and a door that seemed to hang the hinges. Underneath was written "THE ACHARYA HUT." The four people above the hut reflected her own family, and above Ramchandra's head was written, "The Guru of Love". (pp. 200-1)

After the death of Pandey's, their properties legally come to their daughters, Nalini and Goma, because Pandey's do not have any son to claim them. Nalini accepts to own the land and the large mansion Pandey Palace goes to Goma's ownership. Now Ramchandra does not need to worry about the house. Even though no peace regains into him. The house had come to him incidentally but not by his own sweats. He is suffering from patriarchal social psychology that a man living by the maternal property is shameful. He wanders here and there to find another flat at a reasonable price at a proper place which is suitable for his standard. Finally, he decides to return to the same alley in Jaisideval which he left to shift the Pandey Palace long past. Because he used to live for a long time there, he has well acquaintance with almost all people at surrounding. He rents the same flat. Although the flat is more congested, he feels more freedom and comfortable here than the Pandey Palace. He experiences it as his own house and he feels ecstatic.

Ramchandra smiled with his mouth full. For now, he did not want to think about anything; about Goma, about the children, about Malati, about what was happening in the city. He wanted to sit right there, enjoying the view of the people on the street. This was home (p. 272).

The novel has given an ugly and realistic glimpse of Nepal's corrupt bureaucracy through the example of telephone service. Even in the capital, common people, who do not have easy access to the top-level political power and bureaucracy, never get the services and facilities from the government agencies. All types of people; rich and poor, powerful and powerless, educated and uneducated, honest and dishonest, innocent, and criminals live together in the bustling city of Kathmandu. In a materialistic society, upper-class people are indifferent to those who really need support. Urbanization has thrown many children into the street. They live a dirty life begging and wandering to fill their belly.

Ramchandra experiences all sorts of irregularities existing in the city created by both policymakers and ordinary people. He finds all his struggles for a better life in vain. In his original land, life was poor; however, he used to feel relaxed there. These common irregularities that are established as the identity of the city have intensified the tendency of the struggle for existence among the common middle-class people. In addition, negative virtues such as selfishness, jealousy, prejudice, corruption, betrayal, and nepotism have been ruling over all positive virtues. People have become so money-minded that they have made their life harsh and worse themselves. Thus, the protagonist, Ramchandra, is traumatized by his environment and culture. The novelist is successful to depict the trauma of the character socialized in a poor world with a naturalistic and realistic flavor. 


\section{Illicit love-affair}

The naturalists and realists cannot suppress from exposing this biological need. One of the 20th century giant thinkers from the East, Osho (2003) advocated, "sexuality is a biological need for human beings and it shouldn't be suppressed. If it is dominated by force, it reacts as dynamite which can destroy life and that can never be regained" (p. 49). In Nepalese society, illicit lovemaking between a boy and a girl is not easily accepted even in the modern age. It is still taken as a taboo. The bride and groom are arranged by parents and relatives when they are mature enough to get married. In this situation, the love affair between a teacher and his student, which is wonderfully heightened in the novel, is not excused normally.

In the novel The Guru of Love, Ramchandra, a senior mathematics teacher with a wife and two children, falls in love with Malati, his tuition student with an infant. "Love and sex is not the same thing. There is no one definition of love because the word 'love' can mean many different things to many different people, but it embodies the genuine feeling of human instincts. Love is an emotion or a feeling, sex, on the other hand, is a biological event (S. Hendrick \& C. Hedrick, 2002). Even though there are different kinds of sex, most sexual acts have certain things in common. Sex may or may not include penetration. Hannah Tennant Moore (2016) says that sex is an inseparable part of ordinary life. These definitions conclude that 'love' is emotional and 'sex' is both an emotional and physical phenomenon. Nonetheless, both are equally essential for human existence. Love and sex have long been a debatable issue for theologies from the West and the East. The love of man and woman - 'eros' in Greek - is the most commonly used term for interpersonal love. In Buddhism, Kama is sensuous, sexual love. It is an obstacle on the path to enlightenment since it is selfish. In Hinduism, 'kama' is pleasurable, sexual love, personified by the god Kamadeva, the god of sex.

As his part-time profession, Ramchandra tutors Ashok, an SLC (School Leaving Certificate) candidate; the son of a businessman at his flat. One morning, Malati, another SLC candidate, enters his flat to get her tuition class for coming to SLC. She cannot afford the price he asks and so they come to negation in two hundred rupees per month for just two classes a week whereas he charges five hundred rupees per month for whole week classes. The attraction between a male and a female is common when they are together separately. As Ramchandra tutors Malati singl $\mathrm{e}$, he is attracted to her at first glance.

Toward the chill, unusual of late September, she also wore the traditional khasto (cotton-based) shawl. She had long eyelashes and a slim nose; dotted her upper lip. Her hair, glistening with oil, was polled back in a prism style. Malati, she said, was her name, and she appeared slightly older, past her teens than the students he normally tutored. (p. 1)

Malati does not attend the session the next day which panic him. Although there is an agreement with Malati to attend only twice a week, Ramchandra becomes impatient to see her. If it is exposed, it is against social values. The transition between conscious and unconscious mind is the subconscious level of mind. Ramchandra cannot concentrate on his regular duty to take classes normally at his school where he works permanently. He cannot control his unconscious mind. He feels sick and leaves his school that day to go out to find her resident burning mind. Malati is surprised to see her teacher at her hut without early information and she is afraid of her stepmother's possible response. Ramchandra's unexpected visit vibrates Malati's mind and soul, and she keeps wordless about how to respond to him in such a situation, but she becomes sentimental. Then they gradually begin to behave normally. As time passes, they began to date frequently. Now their relationship between a teacher and student changes into lover and beloved. Ramchandra is a married man who already has two children and of the age of her father.

Goma, Ramchandra's wife, appreciates Malati as an innocent girl who needs real help to pass SLC as she is weak in math. SLC examination is taken as an iron gate to enter 
college-level which needs a huge mental and physical effort to pass. From months earlier, students concentrate on SLC. Parents do not like to compromise for their children's education, at least at the iron-gate. Malati, a poor girl, supposes Ramchandra, her teacher, as a guardian, so she is completely dedicated to him and expecting his cooperation to succeed with her examination.

He imagines everything that belongs to Goma to be Malati's. Even on the bed, he imagines Goma to be Malati. As Ramchandra's, Malati's mind does not rest peacefully. When Ramchandra is in front of her, she cannot concentrate her mind on the lesson. There is always burning fire in her mind thinking about Ramchandra's behavior to her and Goma's possible remark to her. She frequently asks him why he is treating her especially like that. "Why do you have to treat me in a special way, sir?" (p. 25). When Malati comes to class Ramchandra feels relaxed at first and the mind concentrates on different parts of the body and gestures, not on the lesson. His head begins burning with fear, passion, and fantasy. Goma does not care about their activities as she is an openhearted woman who, being a Hindu woman, does not suspect her husband. But Ramchandra is in fear of her. He cannot concentrate on his work, family, and everything around him, and at night cannot sleep properly. When Goma hides in another room, he touches Malati's body. During the beginning of the days, he touches her unknowingly. Day after day, his hands reach to her chin, cheeks, hair, and breasts too. Malati does not oppose the activities that encourage him. This irony is reflected realistically.

Then he crosses all demarcations between a teacher and a student. One morning after tuition class finishes, he offers Malati to go to Pashupati during the day. She accepts feeling difficulty. He calls his headteacher asking for leave. They reach nearly rich at first sex inside an abandoned temple near Pashupatibut satirically a monkey disturbs them.

Ramchandra wrapped his hand around Malati's waist and pulled her toward him... They explored each other's mouths, and he squeezed her breasts. She began to moan. He lowered her to the floor- and at once, both of them sneezed from the dust. (p. 88)

It makes them closer to have sexual intercourse at Ramchandra's flat in the absence of Goma and children. Goma suggests Ramchandra ask Malati for lunch on a Saturday. Malati accepts the invitation hesitating. She comes with her infant at the time. Goma and the children treat her as their own family member. The children enjoy being with Malati's daughter, Rachana. Ramchandra and Malati's love affair is facilitated by that invitation.

Under the blanket, both he and Malati were naked, shivering slightly because it was cold. They'd done their lovemaking carefully, because of lack of space and their fear of squashing Rachana. They'd move slowly, their hips grinding against each other. (p. 141)

Osho further believes that "the attraction for sex in the very being of humans is not actually an attraction for sex" (49). The sexual desire in the very core of humanity is actually not a sexual desire. Perhaps the attraction has a very religious significance to it (Crowell, Mosley \& Stevens-Watkins, 2017).

When Malati and Ramchandra's love affair is exposed to her stepmother, she kicks her out of the house. She becomes helpless as she is thrown to open-air on street. Nobody is there to rescue her except Ramchandra. Malati asks Ramchandra to call her to stay with them at least until her examination is finished. Goma views that Malati will, therefore, do better to pass the examination. Goma has also hoped that her effort may help Ramchandra to release from the psychological anxiety that he has been suffering since he is in a relationship with Malati. It is surprising in the context of ordinary society, asking him to share the same room with Malati; she shifts to the children's room at night. In addition, she arranges goat sacrifice asking goddesses to bless Malati for her SLC examination. Ramchandra's in-laws suspect Malati. Mrs. Pandey, his mother-in-law, is more critical to Malati. She often calls her "A whore" (185). 
Ramchandra and Malati both are emancipated by their living together. She improves her math. After the SLC examination, Malati vanishes from Ramchandra's flat getting married to a taxi driver. Ramchandra's anxiety intensified. Goma's anxiety is released. As time passes, Ramchandra releases from psychological illness. Ramchandra's love story described in the novel is not approved by the social rule. However, Upadhyay has been successful to expose the conditions of verisimilitude to Nepalese society. Hence, the novel is the manifestation of naturalism and realism.

\section{Conclusion}

The novel exposes the naturalistic and realistic values that only money is not sufficient for human life. Money cannot purchase peace, harmony, and rejoices. Ramchandra's journey of life faces some physical and psychological obstacles and hindrances. Ramchandra spends his all efforts to achieve a better life. His regular earning manages basic things such as food, shelter, and wearing in nominal quality and quantity but that is not sufficient to live with prosperity. He falls in love with his student Malati. His lust drives him to commit adultery. This relationship fulfills his desire for sex but he can't achieve emancipation. His mind never rests in peace onward. He becomes the subject of a rumor about an immoral teacher who has a sexual relationship with his student. Goma's toleration of his activities enriches his mental throbbing. He himself nearly ruins family life. Malati's voluntary departure releases Goma from tension. In Kathmandu, people love for immediate pleasure which lacks spirituality. In this way, the novel portrays the struggle of a poor teacher in a private school in a poor country with a realistic and naturalistic drive. Ramchandra's temperament and ideology are affected by his environment and heredity. $\mathrm{He}$ is the representative of the common Nepali people.

\section{References}

Barrish, P. (2011). The Cambridge Introduction to American literary realism. Cambridge: Cambridge University Press, 118. ISBN 9780521897693.

Bernstein, R. (2003, August 24). In Nepal too desire defies modern times. New York Times. 19. https://www.nytimes.com/ 2001/08/24/books/books-of-the-timesin-nepal-too-desire-defies-moderntimes.html

Bhagat-Kennedy, M. (2014). Realism in the twentieth-century Indian novel: Colonial difference and literary form. Journal of South Asian Studies, 37(1), 184-185. DOI: 10.1080/00856401.2014.890163

Brussat, Ann and Frederic (2003). The guru of love in spirituality and practice. Book Review. HMC, 3-4

Campbell, D. M. (2017, March 8). Naturalism in American literature. ttps://public.wsu. edu/ campbelld/amlit/natural.htm

Caro, M. De (2011, October 19). Understing naturalism, 624-628. https://www. tandfonline.com/doi/abs/10.1080/0967 2559.2011.608569

Crowell, C., Mosley, D. and Stevens-Watkins, D. (2017, May). Studying sex: A content analysis of sexuality research in counseling psychology. Counsel Psychology, 45(4), 528-546. DOI: $10.1177 / 0011000017713756$.

Dickinson, C. (2003). The guru of love by Samrat Upadhyay. Fiction Reviews. https://www.hackwriters.com/guruoflov e.htm

Dudley, J. (2012, August 29). Realism and naturalism. Oxford bibliographies, 54. https://www.oxfordbibliographies.com/ view/document/obo-9780199827251/ obo-9780199827251-0059.xml.

Hendrick, S. S. \& Hedrick, C. (2002). Linking romantic love with sex: Development of the perceptions of sex. Journal of Social 
and Personal Relationships, 19(3): 361378. DOI: $10.1177 / 0265407502193004$

Joshi, A. (2016, February 5). Reviews on The guru of love by Samrat Upadhyay. Goodreads.com. https://www.goodreads. com/user/show/30148909-anup-joshi.

Kalita, S. M. (2003, January 13). The guru of love teaches marriage is no simple affair. The USA Today. https://www.kirkusreviews.com/bookreviews/samrat-upadhyay/the-guru-oflove/

La, K. (2015, December 18). Reviews on The guru of love by Samrat Upadhyay. Goodreads. com. https: //www.goodreads. com/ user/show/38491379-kenzom-la

Leebron, F. (2003, Spring). Review of The guru of love. Indiatoday. 205. https: //www. indiatoday.in/magazine/societythe-arts/books/story/20030210-bookreview-the-guru-of-love-author-samratupadhyay-793451-2003-02-10

Mehta, S. (2003, January 12). Stuck in the middle in a very high place. New York Times, p. 20.

https://www.nytimes.com/2003/01/12/ books/stuck-in-the-middle-in-a-veryhigh-place.html.

Micheal, D. (1982, July). Realism. Synthese, 52(1), 55-112. https://www.jstor.org/stable/20115760

Milan/zzz (2008, June 6). Reviews on The guru of love by Samrat Upadhyay. Goodreads.com. https://www.goodreads. com/user/show/1218717-milan-zzz

Moore, Hannah T. (2016, February 8). The best literary writing about sex. Retrieved from https://lithub.com/the-bestliterary-writing-about-sex/

Mukharjee, 0. (2013). Review: The city son by Samrat Upadhyay| Kitab. https://kitaab.org/2014/09/03/reviewthe-city-son-by-samrat-upadhyay/
Nair, Rukmini B. (2003, February

11). Samrat Upadhyay's The guru of love. India Today.

https://www.indiatoday.in/magazine/so ciety-the-arts/books/story/20030210book-review-the-guru-of-love-authorsamrat-upadhyay-793451-2003-02-10

Nilges, M. \& Sauri E. (Eds.) (2013). Literary materialism. New York: Palgrave Macmillan. https://doi.org/10.1057/ 97811373399591.

Osho (2003). From sex to superconscious. New Delhi: Full Circle, 49.

Pun, M. (2017, December). The canons of Nepali writing in english. Tribhuwan University Journal, 31(1-2), 63-74. DOI: $10.3126 /$ tuj.v31i1-2.25332

Putnam, H. (2015). Naturalism, realism, and normality. Journal of the American Philosophical Association, 1(2), 312-328. DOI: $10.117 /$ apa.2014.21

Rudder, L. (2013). Naturalism and the first person perspective. Oxford: Oxford University Press.

Samrat Upadhyay's novel The guru of love (2001, August 26). Indiania.com. Retrieved from http://www.indiana.edu/ engweb/faculty/profile_sUpadhyay.sht $\mathrm{ml}$.

Scharnhorst, G. (2017, July). Naturalism and realism. Retrieved from DOI: 10.1093/ acrefore/9780190201098.098.013.509.

Seeman, D. (2002, November). Review of The guru of love. encyclopedia.com. Retrieved from https://www.encyclopedia.com/art s/educational-magazines/upadhyaysamrat

Straus, T. (2001, August 26). Nepali writer's stories of life and love speak to a common truth. San Francisco Chronicle, 23.

Taghizaden, A. (2014, August). A theory of literary criticism. Theory and practice in language studies, 11(8), 1628- 35. London: Academy Publications Co. Ltd. 
The guru of love by Samrat Upadhyay (n. d.). The guru of love by Samrat Upadhyay. Goodreads.com. httpshttps://www.goodr eads.com/book/show/381592.The_Guru _of_Love

The guru of love (n. d.). Reviews on the guru of love. Retrieved from http://www.amazon. com/review

Upadhyay, S. (2003). The guru of love. Boston: Houghton Muffin.

Walsh, B. (2003, March 17). Clueless in Kathmandu: A Nepali Math teacher suffers in The Guru of Love. Times International, 57.

Wheeler, K. (2008). The best travel writing from around the world. Retrieved from https:// books. google.co 